Open Access

\title{
Reluctant civilian world powers? How nationalism threatens the soft power image of Japan and Germany
}

\author{
Patrick Hein
}

\author{
Correspondence: \\ Hein.patrick@ocha.ac.jp \\ Ochanomizu National Women's \\ University, Tokyo, Japan
}

\begin{abstract}
The article examines how Japan and Germany face the challenge of maintaining their self-images of global civilian powers in an unstable and unstructured world order. Both Japan and Germany have been struggling since 1945 with defining and identifying norms and interests that would help them interpret the lessons of history and enable them to act responsibly and constructively in a globalizing world. Even though multilateralism and anti-militarism have characterized the foreign policy of both states in the past, the article holds that Germany and Japan have exposed discrepancies between norms they avow and interests they pursue. It also contends that nationalist policies worsen those discrepancies. Indeed, nationalist ideas of restoring pride and honor in Japan explain why Japan has interpreted its war history differently from Germany. Likewise the quest for an equal military status explains why Germany has endorsed the selective use of force abroad whereas Japan has not. A comparison of migration policies shows that Japan embraces a more closed and descent based concept of nationhood, whereas Germany's national identity norms of openness, respect for difference and tolerance have been strained by nationalist immigration fears and terrorist threats. It is concluded that Japan's and Germany's ability to be perceived as respected international partners depends on their continued ability to act in full agreement with the high principles they claim to hold dear.
\end{abstract}

Keywords: Japan, Germany, Nationalism, Use of force, Integration, Memory politics

\section{Introduction}

The term civilian power has been coined by one of the leading scholars of German foreign policy, Hans Maull, to describe the post-war foreign policies of Germany. This description applies to Japan as well. In Maull's view the goal of a civilian power is not only to improve the world economy, but to civilize international relations through the development of the rule of law, the respect for human rights and human security (Maull 2011). Yet, the realities of international affairs do not match the high ideals expressed in foreign policies. When considering recent trends, it seems that liberal democracies are on the retreat and the international order has undergone fundamental changes. According to findings of the international think thank Freedom House, 'Freedom in the World 2016, global freedom has declined during each of the past 10 years. Such a protracted democratic slump represents a major break from the steady and at times spectacular gains registered from 1975 to 2000 (Freedom House, 2016). In

(c) The Author(s). 2016 Open Access This article is distributed under the terms of the Creative Commons Attribution 4.0 International License (http://creativecommons.org/licenses/by/4.0/), which permits unrestricted use, distribution, and reproduction in any medium, provided you give appropriate credit to the original author(s) and the source, provide a link to the Creative Commons license, and indicate if changes were made. 
addition to the retreat of liberal democracy, superpowers such as Russia or China, for example, have been attempting to defy the foundations of the current world order. On one hand, diplomatic relations between Russia and NATO countries have suffered serious setbacks after the Ukraine and Syria crisis. On the other hand, China's ascendance has marked the limitations of US and Western primacy in the international order. It has challenged the legitimacy of international law and created novel institutions such as the Shanghai Cooperation Organization (SCO) or the Asian Infrastructure Investment Bank (AIIB). Non-state actors such as Islamic State engaging in terrorist acts have also challenged the international order and the German Chancellor Merkel was even compelled in July 2016 to admit for the first time that Germany was engaged in a "war" with Isis (Richter, 2016). At the same time newly established rightwing groups have been on the rise: in Germany, a new right-wing party, the 'Alternative for Germany' (AfD), with about 20,000 members, surged in the polls, benefiting from widespread fears of mass migration and terrorism. In Japan, civil society and the left have been unable to stop the conservative onslaught on previous apology and redress practices (Szczepanska, 2014). Indeed, organizations in support of historical revisionism such as the conservative alliance Nippon Kaigi with about 38,000 members; the anti-Korean hate group Zaitoku-kai with 9,000 to 15,000 members and the anti-comfort women group Nadeshiko Japan with 14,000 members have strengthened their public profile and impact under the Abe administration.

As global economies and international players, Japan and Germany depend on and shape the international world order (Huebner, 2014; Kappel, 2015; Sakaki 2011; Togo, 2015). Hence, both countries have sought permanent membership in the UN Security Council, the central global institution that manages regional and global conflicts. It authorizes the use of military force, adopts international economic sanctions, coordinates international PKO missions, discusses international humanitarian relief activities and has the power to handle international criminal prosecutions and accountability mechanisms. The ability to positively shape the international order reflects not only good practices at home but also reflects and therefore expounds a nation's norms and interests (Matthijs, 2016).

The article assesses Japan's and Germany's practices and commitments in three important policy areas: history acceptance and reconciliation, use of military force and integration norms. A close look at selected policies reveals a somewhat ambiguous picture that revolves around the framing of national identity and security. The article points to contradictory self-images and explains those contradictions in terms of discrepant notions of norm commitments on one side and narratives of national selfcenteredness and self-interest on the other.

\section{Analytical framework: norms, interests and nationalism}

\section{The interplay of norms and interests}

How do we understand the policies of civilian states compelled to operate in a realist and liberal economic world governed by the need for military security and free trade? Neither realism and liberalism nor its rivals, such as normative constructivism, can wholly explain state behaviour (Miyagi, 2012; Sato et al, 2008). First, constructivism seems very persuasive in its argument that norms are derived from identity and constitute filters through 
which national interests are perceived. In his seminal study 'Risk Society' (Beck 1992) the German sociologist Ulrich Beck has argued that the risk category best describes the problems modern societies face (see also Katzenstein, 1996). Beck's sociological risk concept posits that the consequences of modern risks cannot be anticipated, that no one feels responsible for the consequences and that risks do not exist by themselves but are socially defined constructs or scenarios. Maslow et al. (2015) have applied the risk concept of Beck to Japan's foreign policy by contenting that norms such as anti-militarism, developmentalism and isolationism inform the framing, mediation and calibration of risks. They deal through the analytical lens of risk framing - with topics such as the seemingly paradoxical non-recalibration of risks with regard to territorial claims against Russia over the Kuril islands; the politically motivated reframing of the North Korean terrorist threat through Abe in the 2000s; the public opinion divisions in Okinawa over endorsing Abe's militarisation strategy which portrays China as a serious security threat; and environmental issues or the changing of the domestic security discourse since 9/11. During the mediation process various stakeholders such as media, governments, civil society and the market influence the public framing and discursive direction of constructed security risks.

Norms, defined as principled ideas that are worthy of realisation, form the core strategic culture of a state (Junk et al. 2015; Becker 2013). The most important normative framework that informs international relations is the Universal Declaration of Human Rights (and related UN treaties and resolutions) which reflects a historically developed, universally shared understanding of the meaning and importance of human rights (Glendon, 2001). Norms do not lead automatically to improvements as one can see in the chequered history of human rights in practice when states ratify treaties but often do not implement or enforce them. Even though many states violate the normative provisions of the declaration, that does not render the norms superfluous or useless. No one would doubt that we do not live in an ideal world, otherwise the norms leaders cherish would have already become reality and there would no more need for appealing to respect the spirit and letter of the Universal Declaration of Human Rights. In other words, norms such as human rights norms continue to exist precisely because they have not been achieved and because activists across the globe continue to put pressure on states that deny their importance. Hence, G7 foreign ministers confirmed in their 2016 Hiroshima meeting that "universal values" such as democracy, rule of law or human rights do matter and that the G7 stands together to "meet challenges to the universal values" (Joint Communique 2016).

Yet, there is a far-reaching consensus that normative goals are ignored once they collide with hard economic and/or security interests. In addition to that, norms may become blurred, conflicting or contradictory. Harnisch (2013), for example argues, that the same norms that have informed Germany's post-war strategic culture of military restraint were used to justify humanitarian interventions in Kosovo and Afghanistan. Indeed, during the red/green coalition government of Schroeder (1998-2005) the norm 'No more war' was replaced by 'No more Auschwitz' to put it on higher moral ground to justify interventions abroad. Other shortcomings of pure normative concepts are that they rest on abstract, unproven assumptions. To argue, for example, that disaster diplomacy reflects the new national identity of Japan (see Maslow et al., 2015) is problematic because it is assumed that there is a national normative consensus on disaster risk mitigation policies. This is however not the case. Likewise, the constructivist 
concept of ontological security (i.e. maintaining a stable sense of self) is unable to offer a viable explanation for policy reorientations in Japan. The argument advanced by Hagstroem and Gustafsson (2015), that there has been an identity shift in Japan from economic super-power to "that of a law-abiding country, which is threatened and even victimised by morally inferior neighbours" (17) seems not only inaccurate but also biased. Does it mean that, first, countries that pretend or claim to respect laws are de facto always "law-abiding" and, second, that they are "morally" superior to countries that do not pretend so? As mentioned already, norms are not absolute and do not exist by themselves but are embedded in the hard social reality of external pressures, material interests, electoral considerations and power politics. Germany, for example, decided to send ground troops to Afghanistan despite its norms of military restraint and its claim of never starting or participating in a war again. One of the reasons for Germany's intervention was the perceived need of the Schroeder/Fischer government to be internationally recognized and treated as equal military partner. Likewise, Japan decided to resume so-called scientific whaling activities, despite its claim to respect the legally binding ruling by the International Court of Justice against Japan's scientific whaling practices (International Court of Justice 2014). In this specific case the protection of the Japanese fishing industry interests trumped ideational norms of respect for international law. In the same token Japan put pressure on the regional government in Okinawa to approve the prefectural relocation of a US military base, despite very strong local anti-base and anti-militarist sentiments and decided to legalize collective self-defense, even so the Constitution forever renounces war as a means to settle conflicts, even so public opinion has remained anti-militarist in their attitudes and beliefs (Midford, 2011; Vosse et al. 2014) and even though UN Charter article 51 states that collective self-defense is only to last"...until the Security Council has taken measures necessary to maintain international peace and security".

Second, realism (and liberalism) assume that states are motivated by a drive for power, security and the pursuit of national interests (and economic benefits). For IR theory realists rules and principles do not have normative force by themselves. Why, for example, Western governments put pressure on Belarus or North Korea but do not push too far for normative democratic changes in countries such as Saudi Arabia, China or Russia? The answer according to Wolff et al. (2015) is that if economic interests at stake are high, normative calls for democratic change will become weakened (and vice versa). However, one of the weaknesses of realism is that it cannot account for foreign policy moves that may defy realist expectations. Contrary to what realists would have predicted, Japan has so far refrained to exercise international force or proactively counter military threats of North Korea or China. Likewise, as a matter of fact, Japanese elites did not offer bilateral ground support for the US military in Iraq or Afghanistan. Another weakness of realism is that, whether intentionally or not, it fails to address or account for the existence of independent norms that may exist. One example are Western donor interests that may not respond to normative expectations of people in Afghanistan. Thus, normative effects linked to democratization and statebuilding in Afghanistan have been far from guaranteed as normative expectations on the ground have not intersected with Western donor interests (for the reasons see Hakimi, 2015). To sum up the discussion, it makes sense to argue that one hand hard 
factors influence normative choices but on the other hand interests may clash with normative expectations. The next section discusses under what conditions the gap between interests and norms may widen.

\section{The impact of nationalism}

Leaders in Japan and Germany have repeatedly stressed their commitment to the rule of law, liberal democracy, justice, gender equality, human rights and peace. How credible and honest are these commitments and claims in the light of nationalist risks in both states? Beck has observed that a nation-state outlook has governed the sociological imagination - including the classics of sociology. He calls this 'methodological nationalism' and defines it as an approach to studying society where the nation-state is thought of as the main unit of analysis. According to him it is an anachronistic way of thinking as it does not reflect the new realities of cosmopolitanism. He believes that the emergence of the cosmopolitan has contributed to the decay of the traditional nation-state. Beck's framing of cosmopolitan differs from the classic definition offered by Immanuel Kant that the individual is a transcendent individual, a citizen of the world who belongs to humanity as such. By contrast, Beck suggests that cosmopolitanism is a value-free concept by arguing that the mere presence of migrants in a state together with international trade and other exchanges transform it into a cosmopolitan one. He also writes that the "fetish concepts of 'state' and 'nation' - are being hollowed out because in a world risk society, national problems can no longer be solved on a national basis" (Beck 2006, 37). Unlike Beck, who assumes that the nation-state has been transformed into something qualitatively new, I posit that the traditional nation-state has remained the dominant organization principle of the second modernity. Beck's central thesis that the traditional nation-state has been undermined and transformed by the process of reflexive modernization and integrated in a variety of ways into new international regimes and new forms of regionalisms (a state that becomes a showcase of the global) or that "national consciousness, too, is no longer able to provide a basis for stable integration" (Beck et al. 2002:18) seems exaggerated and there is no doubt that he has overestimated cosmopolitization trends in his analysis. The idea that the state is a sovereign actor (representing the identity of territorial space, political community and military power) has not ceased to exist despite (or because of) international institutional frameworks such as IMF, OECD, WTO, EU, NATO, ASEAN, OSCE, UN or international Courts and tribunals. How to maintain and protect national identity and national security is what concerns governments and citizens most. Nationalism challenges what is regarded as appropriate and acceptable civilian soft power conduct. How to define nationalism? Embracing and maintaining a sense of belonging and shared membership is a central feature of modern nationalism. Nationalism describes the internal (unity, belonging and membership) and external (assertion and pride) elements of nationalist policies. Internally, nationalism is directed against minorities, migrants or refugees. People who assume that 'the other' is culturally inferior (different language, customs, religion) assume that their national identity -whatever this means to them- is being threatened by the other. In many European countries, anti-cosmopolitan discourses target the stateless, the undocumented and economic refugees (the "bad" migrants). Externally nationalism is directed against other states. In East Asia, states such 
as China, Japan or Korea argue that their national pride has been violated (in the past) by other states and they like to portray themselves as victims (victims of colonialism, victims of atomic bombings, victims of aggression, victims of foreign occupation, victims of territorial separation). Nationalism worsens the discrepancies and gap between norm commitments and national interests when norms and interests become too much self-centered. One example of self-centered interests is the failed attempt of former German President Horst Koehler to justify the Afghan intervention with national German economic interests and free access to trading routes. Similarly, self-centered norms such as negative victim identity representations espoused in the following section embrace nationalism.

\section{History acceptance norms}

In Beck's model, risks are associated with future events. Nevertheless, the risk model is also helpful in explaining the dynamics of retroactive risk framings and seek an answer to the following question: how can norms account for the ways political actors reinterpret history? In the case of Japan, it can be argued that a negative identity (we were victims of the atomic bomb; of the Japanese military class; of the US occupation forces) warrants a negative concept of nation. Negative beliefs about history can constitute the most serious threat to one's established self-identity. The way history is framed and reinterpreted by national elites can trigger negative reactions and criticisms and is therefore risk enhancing. There have been significant political moves to undermine the fragile national consensus (at least something of a consensus) regarding Japan's recognition of culpability and guilt that seemed to be taking shape since the mid-1990s when former Prime Minister Murayama Tomiichi issued the strongest apology to date (Togo 2013). His statement reflected the belief that Japan should never again fight a war. The problem is that the national consensus on the meaning and importance of peace seems to have broken down after the new Prime Minister Abe Shinzo retook power in 2012. As the Japanese scholar Kawakita Atsuko noted, there is today a palpable confusion about the current meaning of the peace value and its universal connections:

It can be said that Japan's "culture of remembrance" differs from Germany's in that the value of "peace" is placed at the core. However, when examining Germany's "culture of remembrance," I always ask myself many questions about Japan's culture. To what extent is there conviction for maintaining the core value of peace? To what degree does Japan's “culture of remembrance” promote universal values such as democracy and human rights? If our "culture of remembrance" doesn't promote such values, what do we have to strengthen these values? (Kawakita 2015)

As the following sections argue, Kawakita's reflections offer a comprehensive line for further inquiry and discussion. The bonds of modern nationhood are often forged from resources of public or collective memory. In the area of memory politics, I contend that the past has been retroactively reframed in the case of Japan by reemphasizing the norm of victimhood which is associated with the violation of national pride, honor and dignity. Abe has vowed to revoke and revise the, what he calls, masochistic view of history. Convicted World War Two criminals are not regarded as war criminals anymore 
(at least in Japan), the Yasukuni shrine is reframed as a national memorial place of worship, kamikaze pilots died for the future prosperity of Japan and comfort women have been re-casted as licensed, commercial prostitutes. As Gluck (2007) has argued, the Comfort Women's coming into memory was an assault on the heroic narrative of national victimization.

The Japanese standard response to accusations of history whitewashing has been that Japan is not like Germany and that the Japanese did not do the things that Germans did and that therefore it would not be useful to compare Germany's Holocaust to Japanese war atrocities. Japan's Foreign Minister Kishida Fumio repeated this narrative again when he said in 2015 that his country should not be simply compared to Germany in terms of post-World War Two reconciliation. According to him, Japan and Germany differ in terms of what happened during World War Two, under what circumstances they engaged in post-war settlements, and which countries they have as neighbors. "It is inappropriate to simply compare the two nations," Kishida commented (Kishida 2015). The homepage of the Japanese Foreign Ministry was updated in 2015 to reinforce the view that a distinct historical context can account for different approaches:

Compared to Germany, are the measures taken by Japan on issues concerning its past insufficient? Japan and Germany have both dealt with their "history issues" in good faith. At the same time, the historical backgrounds of Germany and Japan differ completely in terms of what happened during the Second World War and under what kind of postwar situation they engaged in postwar settlement. For example, Japan dealt collectively with the issue of reparations with the countries concerned in a manner that was generally accepted by the international community at the time pursuant to the San Francisco Peace Treaty, treaties and instruments. On the other hand, the Government of Japan is aware that Germany took the approach of personal compensation as it could not deal collectively with countries concerning various issues including reparations as Japan did since Germany was divided into East and West following the war. In this way, Japan and Germany have dealt with postwar settlement by different approaches. Therefore, it is not appropriate to make a simple comparison and evaluation of the measures taken by the two countries (Foreign Ministry of Japan 2016)

The above comments infer that the situation and circumstances of each country are unique and that no country should be expected simply to follow the model of another country. Although countries have distinct historical backgrounds and are what they are because of their special and unique pasts, by now they all share (or ought at least to share) a general commitment to universal principles such as criminal accountability, justice, guilt recognition, forgiveness, redress, rule of law, truth or reconciliation (Sang-Jin, 2012; Nabers, 2007). Is it therefore really appropriate to use the term "inappropriate" as Kishida did, a term which implies a morally disallowed or even taboo statement or action? In early 2015, when visiting Japan, German Chancellor Angela Merkel said that Germany's ability to admit history had been an important step toward reconciliation in relations with its neighbors: "there was, (...), also a readiness in Germany to face our history openly and squarely" (Associated Press, 2015). 
Chancellor Merkel's comment to accept history was general enough to be regarded as a guiding normative principle to both countries regardless of specific differences (with regard to settlement issues for example). In the case of Germany, atonement and contrition have been largely accepted by the public and by the political establishment (Berger, 2012). In the case of Japan, international gestures conflict with domestic practices: whilst the letter and spirit of the Kono statement have been uphold, Japanese government officials have refused to recognize comfort women as sexual slaves. While the Abe administration has embraced UN Resolution 1325 on gender equality, it has failed to reflect and incorporate international gender equality commitments in its national action plan.

\section{Normative perceptions regarding the use of military force}

Japan has been struggling to reclaim a secure and stable national identity since being defeated in World War Two (Owada, 2008). The anti-violence norm has shaped Japanese foreign policy since 1945. Japan is not part of any regional military alliance such as NATO and is one the few sovereign states in the world that has renounced forever the right to conduct offensive wars. There have though been strong pushes by conservative elites for more direct bilateral US support contributions on the ground especially since the terrorist attacks on the US in 2001. The deployment experience to Iraq in 2003 was arguably quite different from earlier UN-supporting Japanese missions such as those in Cambodia, Kosovo or Ruanda. The decision to join US forces was contrary to the traditional policy of supporting UN-led peace-keeping missions (PKO) and contrary to Japan's self-imposed five PKO principles. The 1992 peacekeeping law (the PKO Law) had established five principles for participation: (1) a cease-fire agreement among the parties in the conflict; (2) consent by all conflict-parties to peacekeeping forces and to Japan's involvement; (3) strict neutrality by the peacekeeping force; (4) Japan's right to withdraw if the principles are violated; and (5) restrictive use of weapons permitted only at a minimal level for self-protection.

With the 9/11 attacks the LDP saw a chance to overcome the limitations put on SDF operations abroad. The question if Japanese military should participate in missions abroad or not and under what conditions was shifted from a UN perspective to the fight against terror and thereafter to a collective defense perspective. The priority given to the mission in Iraq over UN peacekeeping in Sudan, where the five PKO principles for a Japanese mission had been fulfilled, was a choice influenced by domestic considerations. Domestic considerations influenced also the 2003-2007 reconstruction mission in Samawah, Iraq. With a total of 3,400 dispatched SDF members, the Samawah mission became the largest SDF overseas mission since 1945. Ironically, Japanese soldiers had to be protected around the clock by soldiers from other allied nations such as Australia or the Netherlands, because the mission had to be strictly of a non-combative nature. This means that even in war like dangerous operational environments Japanese soldiers were only equipped with light arms for self-defense and had therefore to be protected for their own safety. The bilateral anti-terror support went in parallel with a decrease in UN peacekeeping support activities. A look at the statistics (see Fig. 1) reveals that Japan reduced its PKO manpower contributions significantly between 2004 and 2010 which corresponds roughly to the time-frame of the SDF mission in Iraq.

As Ishizuka notes, PKO activities were "sidelined" by the decision to support the US: 


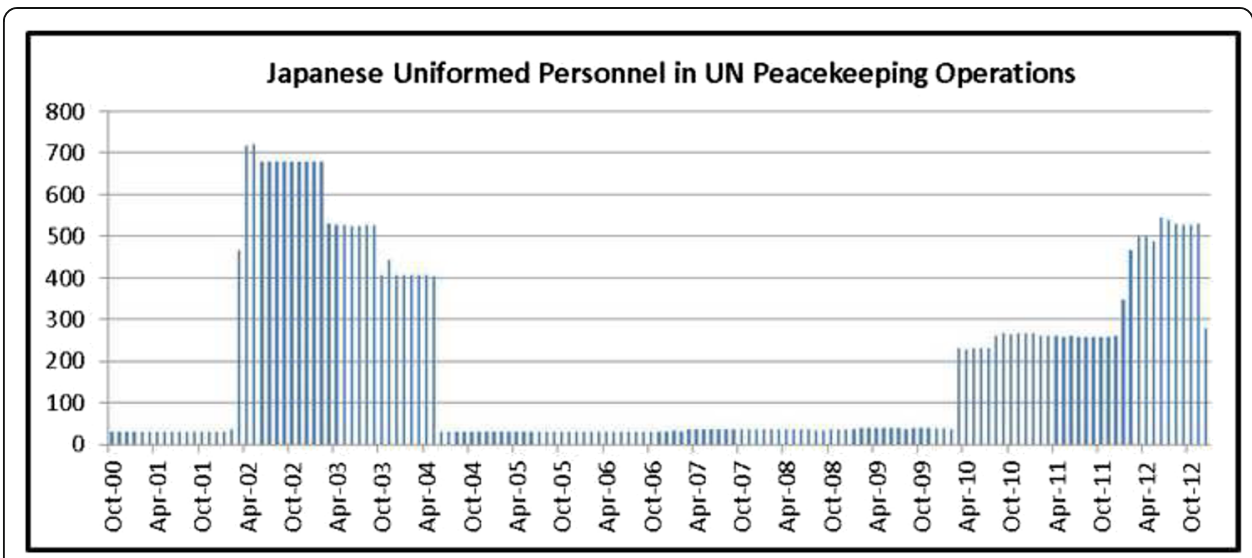

Fig. 1 Japanese PKO personnel 2000 to 2012. Source: http://www.providingforpeacekeeping.org/2014/04/ 03/contributor-profile-japan/

Japan's diminished enthusiasm for UN peacekeeping in the twenty-first century is mainly due to the changing international strategic environment which created new priorities and placed new demands on the SDF. Specifically, after the 9/11 attacks on the United States, Japanese debates about the external use of the SDF shifted from a focus on UN peacekeeping to the "War on Terror," which was framed primarily in terms of the Japan-U.S. alliance. This effectively sidelined UN peacekeeping.

(Peacekeeping Contributor Profile, 2013)

German foreign minister Walter Steinmeier has repeatedly stressed Germany's interdependence with the world (Steinmeier, 2016). Chancellor Merkel has been working towards strengthening NATO's European pillar and building a European defense union (Miskimmon et al. 2015). Compared to Germany's aspirations to be a reliable and trustworthy partner in multilateral missions by NATO, the EU or the UN, Japan has remained focused on its bilateral support for the US in Asia. While Germany has stepped up efforts to contribute globally to diplomatic solutions in the Iran nuclear crisis, the Ukraine crisis and the Syrian crisis, Japan has been concerned with redefining the framework of its exceptional and very close alliance with the US. In his book 'Towards a New Country' (Abe, 2012), Abe has laid out his bold agenda for a more selfconfident Japan. He has been particularly eager to increase what he has coined as 'healthy nationalism' advocating that the country should be far more assertive in its external relations. It is believed that Abe is attempting to give Japan a role in international security more commensurate with the new twenty-first-century era-a role based on the recognition that Japan can (and should) make a greater contribution to regional and global security-as successive U.S. administrations for several decades have urged Japan to do (Hughes, 2015). With the revised U.S. Japan Defense Guidelines issued in April 2015, it has been argued that Japan is strengthening its alliance relationship with the United States in a world of new security challenges, risks and threats. In general terms, Abe is believed to bring the post-War era to a close by removing or at least reducing post-World War Two constraints and thus allowing Japan to assume a greater role as a contributor to security and stability. In July 2014, the Abe administration made a landmark decision to reinterpret Japan's constitution to allow for the exercise 
of collective self-defense. The new interpretation stipulates that Japan can use force when an ally country is attacked and if this attack threatens Japan's survival. According to Hornung et al. (2016) rather than reflecting a new strategy the view is "an expansion of the existing defense-oriented mandate rather than a mandate to exercise the right of collective self-defense" (98). I remains to be seen if the new legislation which came into force in Japan will entail other changes and if Japanese troops will eventually be confronted with armed conflicts outside Japanese territorial borders. The risk exists. The loosening of the strict PKO regulations- by law, SDF personnel can participate in peacekeeping operations only in areas where parties to a conflict have ceased fightingwill make it possible, for example, for SDF forces to become more active and militarily involved in regions such as South Sudan.

\section{Afghanistan case study}

This section explores the policy choices of Germany and Japan in contributing to international security and stability in Afghanistan. Both countries had to consider if they were willing to contribute militarily and under what conditions. Thus, more than 5,000 German troops were stationed in war to Afghanistan from 2002 to 2014. There are two reasons for Germany's intervention in Afghanistan. On one hand, Germany's national self-interests as well as her strive for becoming a powerful actor in political decisions about global security issues within the international community must be stressed. On the other hand, the elimination of historical restrictions on Germany's sovereignty, which resulted from the World War Two experience must be underlined.

The reasons for Germany's increased international military involvement since the 1990s are a mix of normative humanitarian concerns and the quest for external military sovereignty. Germany did not participate in the first US-led Gulf War in 1991 after deciding that it would not participate in military operations that were not sanctioned by a UN Security Council resolution. In July 1994, the federal German constitutional court ruled that participation of German forces in military operations outside NATO territory was permissible as long as such operations were conducted under UN auspices. In the 1999 Kosovo war, however, German fighter planes bombed positions of Serbia in a NATO mission which had no UN mandate. Then, in 2001, the German parliament approved military participation in Afghanistan following adoption of UN resolution 1386. What was the elite thinking behind the use of force in Afghanistan? The pacifist German Green Party coalition partner led by its foreign minister Joschka Fischer was supportive of a humanitarian intervention in Afghanistan because it deemed that war was justified to stop unspecified human rights violations and Taliban terror which was thought to be related to Al-Quaida. For the social-democrats led by Chancellor Gerhard Schroeder humanitarian concerns were not the only reason for intervening. In an interview with a German news weekly, Schroeder rationalized the major paradigm change in German foreign policy as follows:

There was (simply) a consensus in the old Federal Republic that Germany should never take part in another war except to defend the country. SPIEGEL: What made you change your mind? Schroeder: It was the realization that a sovereign country cannot hide behind its past in the long run (Der Spiegel 2013) 
For German elites at the time, remote Afghanistan presented an opportunity to assert national self-interests and get rid of the constraints of "limited sovereignty" (Schroeder). For Schroeder, Afghanistan became instrumental in eliminating the presumed historical restrictions put on Germany's sovereignty:

The Bundestag's decision put an end to the chapter of Germany's limited sovereignty (highlighted by author) after World War II. It made us an equal partner in the international community of nations, one that had obligations to meet, such as those that have arisen from the NATO alliance in the case of Afghanistan (Der Spiegel 2009)

It is noteworthy in this regard to stress that the term "limited sovereignty" was not coined by Schroeder himself, but had been mentioned in the context of German reunification. In 1990 it had been confirmed in a press statement that "The united Germany receives at the moment of its unification its full and unlimited sovereignty" (highlighted by author) meaning at the time that the "four power rights and responsibilities" had been rendered null and void and that Germany's sovereignty over its territory had been fully restored (Gray et al. 1996:245). Limited sovereignty refers in this context to the former lack of authority of Germany to govern itself within its own territorial borders without any interference from outside sources or bodies. For Schroeder, who had been dissatisfied with Germany being perceived by the world as paymaster, Afghanistan presented an opportunity to engage and test Germany's military capabilities for the first time since 1945 by dispatching German ground forces to a remote conflict (Hacke, 2008). Interestingly, the conservative Merkel has endorsed the social-democrat Schroeder in her assessment of the situation in Afghanistan. In a major government declaration on Afghanistan from 2009 Merkel justified the German mission to: "protect the lives of people in Germany from the evil of international terrorism" (Associated Press, 2009). That being said, the argument connecting German national security to the Taliban threat has remained, vague and weak. The military parliamentary mandate that was formulated, reflected a cautious, reluctant and maybe even delusive national perspective. This logic ultimately led to the acceptance of the offensive use of force. The biggest damage to Germany's reputation as highly respected civilian power was caused in 2009, when a German airstrike resulted in the death of many civilians in the Kunduz region. Kunduz became a deep source of criticism against German military involvement in Afghanistan. The defensive mandate given to soldiers had not matched the reality on the battleground and the strict field operations manual guidelines (rules of engagement) issued by the US commandment to ensure that no civilians become unintended targets of NATO airstrikes had not been observed by the acting German field commander. This resulted in the significant loss of lives and the entanglement of German soldiers in offensive counterinsurgency operations. Even though no one was held criminally or legally accountable, the deadly airstrike had serious consequences for some: Germany's Army Chief of Staff resigned in late 2009 over the airstrike. In late May 2010, the German President Horst Koehler followed and resigned after a row over remarks where he had linked the use of military force in Afghanistan to the protection of legitimate German national economic interests.

By contrast, Japan had pledged that it would fulfill its international responsibilities without fighting on the ground. From the beginning of the conflict there was a strong 
elite driven consensus to keep the SDF completely out of Afghanistan in line with Japan's strict normative policy of not using force or endangering the lives of soldiers or civilians. Nevertheless, Japan's important contribution to the reconstruction of Afghanistan from 2001-2013, which did not involve deployment of the SDF required new civil-military cooperation in Japan's overseas development assistance policies (Yasutomo 2014). Japan contributed in two major areas: it trained police personnel and coordinated the demobilization of former Taliban fighters. Besides, Japanese NGOs offered development cooperation expertise. The Japanese decision not to get militarily embroiled in Afghanistan has been congruent with its civilian attitudes. By contrast, the German decision to contribute militarily has not produced the expected results in terms of public security, civilian reconstruction and the rule of law. The Japanese civilian centered approach appears in hindsight more adapted to the human security needs of the Afghan people, compared to the German military centered approach built upon the premise of military stabilization and securitization. It remains to be seen whether the aim of securing Afghanistan has justified the means (military intervention) and whether the military mission will be successful or not in the long term i.e. whether an international terrorist threat no longer emanates from Afghanistan.

Table 1 captures German and Japanese participation in United Nations, NATO and EU led military missions abroad. Compared to Japan Germany has paid a heavy price for its military NATO, UN and EU engagement. Indeed, it has lost more than 100 soldiers since 1990, whereas not one single Japanese soldier has been killed (in combat operations overseas) during the same time-frame. There are as of this writing 16 ongoing UN peacekeeping operations led by the UN Department of Peacekeeping Operations.

\section{Integration/assimilation versus exclusion norms}

Germany and Japan are two countries whose immigration policies have traditionally been associated with descent (jus sanguinis), a principle which posits that descendants can only be full German or Japanese citizens if born to German or Japanese parents. Both states, in their different ways, have historically adhered to a discourse of belonging called an assimilationist ethno-centrist approach. Both states switched to more restrictive, exclusive regimes for political reasons. Germany had largely been a nation of emigration prior to 1890. Before that, most German states practiced jus domicili (right of domicile). It meant that extended residence gave a guarantee to obtain German citizenship. Early forms of state citizenship in Germany were based on residence (domicile)-not on ethnic criteria- simply to exclude incoming poor alien migrants (many of whom were ethnically German) from receiving economic benefits. At the same time, under the Prussian citizenship law of 1842, ten years of continuous residence abroad meant -in principle- the loss of German citizenship. After 1890 the German Reich and its booming economy attracted many foreign labour migrants. These were regarded by the German states as a cheap labour reserve that could be used to fill labour force gaps. Between 1890 and 1910 the number of foreign nationals had tripled from 430,000 to $1,260,000$. Inclusion into the German nation via naturalization was becoming almost impossible with the adoption of the jus sanguinis principle by the new 1913 citizenship law. Indeed, Brubaker (1992) traces the descent-based approach 
Table 1 Overseas military missions of Germany (UN, NATO, EU) and Japan (UN, US led) since 1990

\begin{tabular}{|c|c|c|}
\hline & Germany & Japan \\
\hline 1991 & & $\begin{array}{l}\text { Minesweepers Persian Gulf to support US } \\
\text { war effort in Iraq }\end{array}$ \\
\hline 1992/1993 & Cambodia UNTAC mission & Cambodia UNTAC mission \\
\hline \multirow[t]{2}{*}{ 1993/94 } & UN mission Somalia & UN mission Mozambique \\
\hline & & UN Golan Heights observer mission \\
\hline 1999-as of this date & $\begin{array}{l}\text { NATO led mission (Kfor) in } \\
\text { Ex-Yugoslavia }\end{array}$ & \\
\hline 2001-2010 & & $\begin{array}{l}\text { Maritime refueling logistic support for the } \\
\text { US in the Indian Ocean }\end{array}$ \\
\hline 2004 & & $\begin{array}{l}\text { Troops stationed from } 2003 \text { to } 2007 \text { in } \\
\text { Iraq in support of US war against terror }\end{array}$ \\
\hline since 2006 & UN led mission in Libanon & \\
\hline \multirow[t]{2}{*}{ since 2008} & UN led mission in Darfur (Sudan) & \\
\hline & EU Atalanta mission Somalia & \\
\hline \multirow[t]{2}{*}{ Since 2009} & & $\begin{array}{l}\text { Maritime anti-piracy support in the Gulf } \\
\text { of Aden (Somalia) }\end{array}$ \\
\hline & & Set up permanent military base in Djibouti \\
\hline Since 2011 & UNMIS mission in South Sudan & UNMIS mission in South Sudan \\
\hline 2002-2014 & ISAF-Nato mission in Afghanistan & \\
\hline since 2012 & Nato active fence mission in Turkey & \\
\hline \multirow[t]{3}{*}{ since 2015} & $\begin{array}{l}\text { Nato resolute support force in } \\
\text { Afghanistan }\end{array}$ & \\
\hline & Military advisers in Iraq & \\
\hline & Germany sends Tornado jets against IS & \\
\hline from 2016 & $\begin{array}{l}\text { Increase German contingent in Mali } \\
\text { up to } 700 \text { soldiers }\end{array}$ & \\
\hline $\begin{array}{l}\text { Peak number abroad at } \\
\text { one point in time }\end{array}$ & $4,000(10,000$ up to 2002$)$ & 600 \\
\hline Total number dispatched & 380,000 & 9,300 \\
\hline total number of missions & 56 & 13 \\
\hline killed in action & 103 & 0 \\
\hline Updated status 2016 & $\begin{array}{l}\text { At present, Germany has a total of } \\
3.364 \text { soldiers abroad on various } \\
\text { missions (thereof PKO total: 200) }\end{array}$ & $\begin{array}{l}\text { At present, Japan contributes a 272-strong } \\
\text { engineering unit to the UN Mission in the } \\
\text { Republic of South Sudan }\end{array}$ \\
\hline
\end{tabular}

Sources: https://de.wikipedia.org/wiki/Auslandseinsätze_der_Bundeswehr for Germany and http://apjjf.org/2014/12/31/ Narusawa-Muneo/4158/article.html for Japan (own compilation)

to citizenship and migrants at least to a 1913 law of citizenship - if not to the 1842 Prussian citizenship law. From then, residency (domicile) was not anymore a criteria for citizenship as it used to be. This law was meant to allow German emigres in former German colonies to retain their citizenship.

In Japan's case, the political turn from a multiethnic to a homogenous state occurred only after 1945 . The post-war immigration control norm has been consistent and stable over a long period in Japan. Since 1952, the year of the San Francisco Peace Treaty, the narrative of the homogenous, mono-cultural nation has not significantly changed. In terms of policy implications. Japan has been relatively reclusive since 1952. Former 
Taiwanese, Chinese and Korean imperial subjects have been stripped of their Japanese citizenship. Asylum seekers and refugees have been rejected at the borders. Foreignborn ethnic Japanese (so called Nikkei) have been encouraged to return home. As a result, Japan has a very low percentage of non-Japanese nationals (1.5 \%). Oguma (2002) has challenged the commonly held belief that Japanese mono cultural or homogeneous cultural thinking appeared in the Meiji and Taisho eras and then perpetuated itself during and after World War Two. Oguma instead claims that during Meiji and Taisho eras, and even during much of the wartime period, Japan had considered itself a very strong multiethnic nation, and that the image of homogeneity actually arose at the end of 1945 and became a concrete idea only well after World War Two. After the loss of its imperial colonies in 1945, Japan reframed nationality laws in terms of ethnic homogeneity. Hence, former colonial Korean and Chinese subjects lost their former privileges such as Japanese citizenship and voting rights. The legal status of former imperial subjects from Korea and Taiwan shifted from being Japanese citizens to becoming foreign nationals with the signing of the San Francisco Peace Treaty of 1952. Their history exemplifies the narratives of assimilation, discrimination, exclusion, and hardship. Likewise, Germany passed laws making German nationality almost completely a function of having German parents and belonging to the ethnic category of German Volk (people).

\section{Nikkei/Aussiedler case study}

A comparison of the Nikkei (Latin Americans-mostly Brazilians and Peruvians of Japanese Origin) and of the Aussiedler (ethnic German repatriates who moved to Germany from Eastern Europe) case shows that ethnic descendance does not automatically qualify for membership and inclusion. The two groups present several similarities: both groups are composed of ethnic descendants from the country of origin, both groups have been actively targeted for immigration and both groups neither spoke the local language nor did they possess special economic skills. Although Germany, like Japan, mandates jus sanguinis, it implements the principle in a manner broad enough to include all people of German ancestry as eligible to return to Germany and become German citizens. The mass migration of ethnic Germans to Germany occurred in two phases. In the first phase mass migration was facilitated by political developments related to the radical transformations in neighboring communist countries. Before 1990, it was assumed that repatriates from Eastern Europe (former USSR, Poland, Romania etc.) had been discriminated and therefore had the right to freely enter Germany and become automatically German citizens. The German term Vertreibungsdruck (expulsion pressure) assumed that living conditions in communist countries made it impossible for ethnic Germans to stay. Aussiedler could enter Germany without restrictions until 1989, when the Berlin wall fell. During the second phase after the collapse of communism, German laws were tightened: repatriates had to provide documentary proof of German descent or present evidence that they had German roots or ties (speak German, know German culture) and had to pre-apply for entry to Germany in their country of origin. Despite the tightening of ethnic criteria, a huge number of ethnic Germans became German citizens. As of today almost 4.5 million repatriates live in Germany. They presently constitute Germany's largest immigrant group before the Turkish immigrant community. 
Under the Japanese immigration policy after 1990, when the revised immigration law took effect, second-generation South American descendants (Nisei) of Japanese nationals born on or before the end of World War Two were made eligible for a (renewable) three year special working visa while third generation descendants and their spouses (Sansei) were entitled to a (renewable) one year visa. To apply, applicants had to provide an official copy of their birth certificate and of the family registry-which serves as proof of Japanese nationality- of one parent from the home town in Japan to the Japanese embassy in their country of origin. Later-generation Japanese descendants (Yonsei or fourth generation) were excluded from the visa program because the links of ancestry were deemed too weak.

The biggest difference in the basic approach between Germany and Japan has been the naturalization issue: whereas Germany, by granting German citizenship to ethnic Germans, gave repatriates a secure and equal legal status, the Japanese Government had from the beginning no intention to confer Japanese citizenship to migrants of Japanese ancestry or to put them on equal terms with Japanese citizens. Instead, Nikkei were legally treated and considered as foreign nationals with a restricted resident status limiting their period of stay and confining them de facto to unskilled labor.

Despite the liberalization of citizenship laws and regulations in Germany there has been a shift from traditional discourses of modern nation-state-belonging rooted in the right of blood to new markers of difference such as religious affiliations, education level or cultural competence. This suggests that whereas race and ethnic origin were prominently used in the past for the construction of the other, cultural, religious, or educational markers have been added to distinguish the majority from the minority. Islam has become the central symbol-if not stigma-of religious and cultural otherness in Germany. The rightwing party AfD has claimed that Islam as such does not belong to the German national heritage, because it does not respect the Constitution and basic German values. The debate about multicultural society has been led by liberal and conservative forces alike. In 1996, the liberal German-Syrian Islam scholar Bassam Tibi, concerned about about the radicalization of both Islamist and anti-Islamist movements, proposed the Leitkultur (English: "reference culture") concept to overcome intolerance and erase misperceptions. Values can either be imposed in coercive ways through violence and indoctrination or shared in positive ways through respect, tolerance, acceptance, and understanding. According to Tibi, the Leitkultur concept encompasses the usage of reason, commitment to the Constitution and individual human rights, separation of religion and state, pluralism, human dignity, and mutual tolerance (Tibi, 2008; Tibi, 2001). Likewise, the principle of constitutional patriotism, a concept associated with the liberal German scholar Juergen Habermas posits that citizenship is defined by shared, universal republican or democratic values, rather than by a common history or ethnic origin. For many Germans, articles 1-19 of the German Constitution (the so called Basic Law) symbolize Leitkultur in the sense of inalienable, basic human rights. Conservative circles have contested this republican and secular vision. For leading German conservatives such as Norbert Lammert, president of the German parliament, loyalty toward the constitution is insufficient. Leitkultur must reflect the common cultural roots of Germany and in a larger sense of Europe such as the shared history and the shared Christian religious thoughts and traditions (Lammert, 2006). 


\section{Conclusion}

The article discussed the foreign policy choices of Japan and Germany in an increasingly unstable world characterized by a retreat of liberal democracy. Both countries have struggled most with the question of how to reconcile legitimate national interests with universally shared norms. From a theoretical perspective it was stressed that although realist interests often determine policy outcomes it may also happen that interests clash with norms, that interests are constrained by norms or that norms conflict with other norms. When norms or interests are too much self-centered nationalism may widen the gap between interests and norms. The article analyzed three policy areas where realist strategies did not match normative expectations thus limiting the ability to shape the international environment in constructive ways. In the area of use of force Germany employed a realist military strategy in Afghanistan, whereas Japan pursued a non-military civilian reconstruction approach. The allegedly just and selective use of military force against the Taliban in Afghanistan under the banner of fighting against international terrorism was justified with threats to national security by German elites and the wish to be treated as equal partner. However, the argument connecting German national security to the Taliban threat was found to be vague and unconvincing.

The Japanese decision to give bilateral support to US military operations in Iraq and Afghanistan rather than supporting UN mandated peacekeeping missions has created similar foreign policy contradictions. Indeed, Japan aims at being fully supportive of multilateral institutional peace enhancing mechanisms, but at the same time it considers the alliance with the United States as the cornerstone of its foreign policy.

In the area of immigration policies it was shown that even though Germany evolved from an ethno-centrist state to a country of immigration with open borders it has continued to promote essentialist notions of German lead culture (i.e. subscribe to the Christian roots of European civilization). In the Japanese case, it was argued that decisions about membership or belonging have been subordinated to the traditional nation-state narrative: migrants of Japanese descent were framed as non-Japanese nationals expected to assimilate completely into mainstream Japanese society without being granted equal rights. Japan has continued to act as an ethno-centrist state with tight border and immigration controls.

It was further argued that modern norms such as humanitarian intervention, for example, are not necessarily superior to existing norms nor do they suggest a transition to a cosmopolitan system as predicted by Beck. In addition, the article argued that some norms have remained relatively stable and consistent namely anti-violence in Japan, ethnicity based immigration norms in Japan and Germany or culture of contrition and remembrance in Germany, whereas other norms such as the use of military force and revised representations of the past have been inconsistent or atypical.

The German use of military force in Afghanistan has illustrated that a defensive military mandate in a war zone cannot be uphold. Germany has abandoned this strategy since and declined for example to take part in the 2011 Libya air strikes. Hence, the Afghan experience has not fundamentally affected the peace enhancing continuity of German foreign policy. The biggest challenge for Germany will be to stick to and pursue national interests that comply with universally shared values and norms. To put it differently, military missions that are not perceived as enhancing peace and security will 
damage its civilian peace broker reputation. Post-war Japan never used military force abroad, yet its inability to accept history and reconcile with its key neighbours show that Japan does not live up to the universally shared norms it claims to firmly uphold. In the Japanese case, the past has been retroactively reframed again and again by conservative and rightwing groups emphasizing a sense of national victimhood incurred during World War Two, insisting that the Constitution was forcefully imposed by the US, that the war against Asian nations was not an aggression, that comfort women were no sexual slaves, that kamikaze died for the future prosperity of Japan, that Japanese war criminals were not criminals. Japanese elites have struggled to define and redefine what they did in the past and how this affects their role in the current world affairs. The biggest challenge for Japan will be the reconciliation of contested historical representations with the need to be seen as acting in agreement with those historical narratives.

\section{Acknowledgement}

The author would like to thank the anonymous reviewers for their comments. This is to acknowledge that no founding from third parties was received.

\section{Competing interests}

The author declares that he has no competing interests.

Received: 24 August 2016 Accepted: 28 October 2016

Published online: 14 November 2016

\section{References}

Abe, Shinzo. 2012. Atarashi Kuni He (Toward a New Country). Tokyo: Bunshun Shinsho.

Associated Press. 2009. German leader: No rushed judgment on Afghan strike. http://en.trend.az/world/other/1536919. html. Accessed 15 Jan 2016.

Associated Press. 2015. Merkel: Facing WW II Atrocity Key to German Reconciliation. https://sg.news.yahoo.com/merkelfacing-ww-ii-atrocity-key-german-reconciliation-055609064.html. Accessed 20 May 2015.

Beck, Ulrich. 1992. Risk Society. London: Sage.

Beck, Ulrich. 2006. The Cosmopolitan Vision. Cambridge/Malden: Polity Press.

Beck, Ulrich, and Beck-Gernsheim Elisabeth. 2002. Individualization: Institutionalized Individualism and its Social and Political Consequences. London/Thousand Oaks/New Delhi: Sage Publications.

Becker, Sabine. 2013. Germany and War: Understanding strategic culture under the Merkel government. www.defense. gouv.fr./. Accessed 17 Dec 2015.

Berger, Thomas. 2012. War, Guilt, and World Politics after World War II. Cambridge: Cambridge University Press.

Brubaker, Rogers. 1992. Citizenship and Nationhood in France and Germany. Cambridge: Harvard University Press.

Der Spiegel. 2009. Essay by Former Chancellor Gerhard Schroeder: The Way Forward in Afghanistan. http://www. spiegel.de/international/world/essay-by-former-chancellor-gerhard-schroeder-the-way-forward-in-afghanistan-a607205.html. Accessed 1 Aug 2016.

Der Spiegel. 2013. Gerhard Schroeder: Germany Can Only Lead Europe the Way Porcupines Mate. http://www.spiegel. de/international/germany/interview-former-german-chancellor-gerhard-schroeder-on-foreign-policy-a-891839.html. Accessed 24 June 2015.

Foreign Ministry of Japan. 2016. History Issues Q \& A. http://www.mofa.go.jp/policy/q_a/faq16.htm.l. Accessed 1 Dec 2016.

Freedom House. 2016. Q \& A: 10 Years of Decline in Global Freedom. https://freedomhouse.org/blog/q-10-yearsdecline-global-freedom. Accessed 10 Jan 2016.

Glendon, Mary. 2001. A World Made New: Elanor Roosevelt and the Universal Declaration of Human Rights. New York: Trade Paperbacks.

Gluck, Carol. 2007. Operations of Memory: 'Comfort Women' and the World. In Ruptured Histories: War, Memory, and the Post-Cold War in Asia. Jager and Mitter eds.47-77. Cambridge: Harvard University Press.

Gray, Richard T, and Sabine Wilke. 1996. German Unification and Its Discontents Documents from the Peaceful Revolution. Seattle and London: Washington University Press.

Hacke, Christian. 2008. German foreign policy mirrored in the achievements and shortcomings of its chancellors. In Routledge Handbook of Diplomacy and Statecraft, ed. B.J.C. McKercher, 87-96. London and New York: Routledge.

Hagstroem, Linus, and Karl Gustafsson. 2015. Japan and identity change: why it matters in International Relations. The Pacific Review 1: 1-22.

Hakimi, Aziz. 2015. Getting savages to fight barbarians: Counterinsurgency and the remaking of Afghanistan. In The Afghan Conundrum: Intervention, Statebuilding and Resistance. Jonathan Goodhand and Mark Sedra eds), 388-405. London: Routledge.

Harnisch, Sebastian. 2013. German Foreign Policy: Gulliver's travails in the 21st century. In: Foreign Policy in Comparative Perspective. Beasley, Ryan K. et al. (Eds). 71-93. Washington D.C.: CQ Press.

Hornung, Jeffrey W. and Mochizuki, M. Mike. 2016. Japan: Still An Exceptional U.S. Ally in The Washington Quarterly Volume. The Washington Quarterly. 39:1: 95-116. 
Huebner, Karl. 2014. Europeanisation and Globalisation as Drivers of the German Growth Model. In The Routledge Handbook of German Politics \& Culture, ed. S. Colvin, 391-408. London: Routledge.

Hughes, Christopher W. 2015. Japan's Foreign and Security Policy Under the 'Abe Doctrine': New Dynamism or Dead End? New York: Palgrave.

International Court of Justice (ICJ). 2014. Whaling in the Antarctic (Australia v. Japan: New Zealand intervening). www. icj-cij.org/docket/files/148/18162.pdf. Accessed 4 Aug 2016.

Joint Communique. 2016. G7 Foreign Ministers' Meeting April 10-11, 2016 Hiroshima, Japan. www.japan.go.jp/g7/_ userdata/common/data/000147440.pdf. Accessed 1 Sept 2016.

Junk, Julian, and Christopher Daase. 2015. Germany. In Strategic Cultures in Europe. Volume 13 of the series Schriftenreihe des Zentrums für Militärgeschichte und Sozialwissenschaften der Bundeswehr, ed. Biehl Heiko, Bastian Giegerich, and Jonas Alexandra, 139-152. Wiesbaden: Springer.

Kappel, Robert. 2015. Global Power Shifts and Germany's New Foreign Policy Agenda. Strategic Analysis 38(3): 341-352. Katzenstein, Peter. 1996. Cultural Norms and National Security. New York: Cornell University Press.

Kawakita, Atsuko. 2015. Facing History-Germany's culture of remembrance. http://www.yomiuri.co.jp/adv/chuo/dy/ research/20140703.html. Accessed 10 Sept 2015.

Kishida, Fumio. 2015. Press Conference by Foreign Minister Fumio Kishida. http://www.mofa.go.jp/press/kaiken/kaiken4e_ 000149.html. Accessed 15 July 2015.

Lammert, Norbert. 2006. Verfassung - Patriotismus - Leitkultur: Was unsere Gesellschaft zusammenhaelt. Bonn: Bundeszentrale fuer politische Bildung.

Maslow, Sebastian, Ra Mason, and Paul O'Shea. 2015. Risk State: Japan's Foreign Policy in an Age of Uncertainty. Farnham: Ashgate.

Matthijs, Matthisa. 2016. The Three Faces of German Leadership. Survival 58(2): 136-154.

Maull, Hans. 2011. Globalization and German Foreign Policy. library.fes.de/pdf-files/ipg/2011-2/12_a_maull.pdf/. Accessed 9 Aug 2016.

Midford, Paul. 2011. Rethinking Japanese Public Opinion and Security: From Pacifism to Realism? Stanford: Stanford University Press.

Miskimmon, Alister, and Luuk Molthof. 2015. Germany's foreign policy: challenges and opportunities after the federal election in 2013. In Germany After the 2013 Elections: Breaking the Mould of Post-Unification Politics? ed. G. D'Ottavio and T. Saalfeld, 67-89. Farnham: Ashgate.

Miyagi, Yukiko. 2012. Japan's Middle East policy: 'still mercantile realism', International Relations of the Asia-Pacific. International Relations of the Asia-Pacific. 12. 2:287-315.

Nabers, Dirk. 2007. How to be good: morality in Japan's and Germany's Foreign Policy. In The Ethics of Foreign Policy, ed. D.B. MacDonald, 117-135. Aldershot: Ashgate.

Oguma, Eiji. 2002. A Genealogy of Japanese Self-Images. Melbourne: Trans Pacific Press.

Owada, Hisash. 2008. In search of a new national identity: an analysis of the national psyche of post-war Japan. In A New Japan for the $21^{\text {st }}$ Century. An Inside Overview of Current Fundamental Changes and Problems, ed. R.T. Segers, 235-249. London: Routledge.

Peacekeeping Contributor Profile. 2013. Japan. http://www.providingforpeacekeeping.org/2014/04/03/contributorprofile-japan/. Accessed 17 May 2016.

Richter, Konstantin. 2016. The end of Germany's golden age. http://www.politico.eu/article/the-end-of-germanysgolden-age-chancellor-angela-merkel-mood-shift-refugees-economy-afd/. Accessed 7 July 2016.

Sakaki, Alexandra. 2011. Germany and Japan as Regional Actors in the Post-Cold War Era: A Role Theoretical Comparison. Ph.D. thesis.

Sang-Jin, Han. 2012. Divided nations and transitional justice: what Germany, Japan, and South Korea can teach the world. Boulder: Paradigm.

Sato, Yoichiro, and Keiko Hirata. 2008. Norms, Interests, and Power in Japanese Foreign Policy. New York: Palgrave MacMillan.

Steinmeier, Walter. 2016. Ruptures and Bridges - German Foreign Policy in Turbulent Times, A talk by Foreign Minister Frank-Walter Steinmeier as part of the GIGA Distinguished Speaker Lecture Series. http:/www.auswaertiges-amt.de/ sid_B1B3676D9DFA387D7A700036C376E1CC/DE/Infoservice/Presse/Reden/2016/160627-BM-GIGA.html/. Accessed 19 Sept 2016

Szczepanska, Kamila. 2014. The Politics of War Memory in Japan: Progressive Civil Society Groups and Contestation of Memory of the Asia Pacific War. Abingdon: Routledge.

Tibi, Bassam. 2001. Islam between Culture and Politics. New York: Palgrave.

Tibi, Bassam. 2008. Political Islam, World Politics and Europe. London: Routledge.

Togo, Kazuhiko. 2015. Japan's Foreign Policy 1945-2003: The Quest for a Proactive Policy. Boston: Brill.

Togo, Kazuhiko. 2013. Japan and Reconciliation in Postwar Asia, The Murayama Statement and Its Implications. New York: Palgrave.

Vosse, Wilhelm; Drifte, Reinhard and Blechinger-Talcott, Verena (eds.). 2014. Governing Insecurity in Japan. The Domestic Discourse and Policy Response. Abingdon, Oxon, New York: Routledge.

Wolff, Jonas and Spanger, Hand-Joachim. 2015. The interaction of interests and norms in international democracy promotion. Journal of International Relations and Development. 1-28. http//link.springer.com/article/10.1057/jird.2014.33.

Yasutomo, Dennis T. 2014. Japan's Civil-Military Diplomacy: The Banks of the Rubicon. Abingdon: Routledge. 